\title{
Chickpea chlorotic stunt virus: A New Polerovirus Infecting Cool-Season Food Legumes in Ethiopia
}

\author{
A. D. Abraham, W. Menzel, D.-E. Lesemann, M. Varrelmann, and H. J. Vetten
}

First, second, third, and fifth authors: Federal Biological Research Center for Agriculture and Forestry (BBA), Institute of Plant Virology, Microbiology and Biosafety, Messeweg 11-12, 38104 Braunschweig, Germany; and fourth author: University of Göttingen, Institute of Plant Pathology and Plant Protection, Grisebachstr. 6, 37077 Göttingen, Germany.

Current address of A. D. Abraham: Ethiopian Agricultural Research Organization, National Plant Protection Research Centre, P.O. Box 37, Ambo, Ethiopia.

Accepted for publication 18 January 2006.

\begin{abstract}
Abraham, A. D., Menzel, W., Lesemann, D.-E., Varrelmann, M., and Vetten, H. J. 2006. Chickpea chlorotic stunt virus: A new polerovirus infecting cool-season food legumes in Ethiopia. Phytopathology 96:437446.

Serological analysis of diseased chickpea and faba bean plantings with yellowing and stunting symptoms suggested the occurrence of an unknown or uncommon member of the family Luteoviridae in Ethiopia. Degenerate primers were used for reverse transcriptase-polymerase chain reaction amplification of the viral coat protein $(\mathrm{CP})$ coding region from both chickpea and faba bean samples. Cloning and sequencing of the amplicons yielded nearly identical $(96 \%)$ nucleotide sequences of a previ-

isolate comprised six major open reading frames characteristic of poleroviruses. Of the four aphid species tested, only Aphis craccivora transmitted the virus in a persistent manner. The host range of the virus was confined to a few species of the family Fabaceae. A rabbit antiserum raised against virion preparations cross-reacted unexpectedly with Beet western yellows virus-like viruses. This necessitated the production of murine monoclonal antibodies which, in combination with the polyclonal antiserum, permitted both sensitive and specific detection of the virus in field samples by triple-antibody sandwich, enzyme-linked immunosorbent assay. Because of the characteristic field and greenhouse symptoms in chickpea, the name Chickpea chlorotic stunt virus is proposed for this new member of the genus Polerovirus (family Luteoviridae).
\end{abstract} ously unrecognized species of the family Luteoviridae, with a CP amino acid sequence most closely related (identity of $\approx 78 \%$ ) to that of Groundnut rosette assistor virus. The complete genome (5,900 nts) of a faba bean
Additional keywords: aphid transmission, decoration titer, electron microscopy, sequence analysis, Turnip yellows virus.
Ethiopia is a primary producer of food legumes with production in 2003 estimated to be over 1 million metric tons produced on nearly 1.2 million hectares (16). The majority (87\%) of the production consists of cool-season food legumes, such as chickpea (Cicer arietinum L.), faba bean (Vicia faba L.), field pea (Pisum sativum L.), and lentil (Lens culinaris Medik.). Virus diseases are among the important biotic constraints for the production of these crops. About 10 viruses have been identified by serological means from these crops in Ethiopia $(1,2,62)$. While Pea seed-borne mosaic virus chiefly infects lentil, members of the family Luteoviridae (luteovirids) such as Soybean dwarf virus (SbDV) and Beet western yellows virus (BWYV) appear to be very common in both chickpea and lentil $(1,62)$. In faba bean, the nanovirus Faba bean necrotic yellows virus (FBNYV) and, in particular, a number of unidentified luteovirids seem to be widespread in Ethiopia (2). The latter viruses appear to be the predominant cause of yellowing and stunting diseases of cool-season food legume crops in Ethiopia. This also includes chickpea stunt, which is considered the most important chickpea disease after fungal wilt and root rot disease (30).

Corresponding author: H. J. Vetten; E-mail address: h.j.vetten@bba.de

Nucleotide sequences reported here are available under accession nos. AY956384 and AY956385.

DOI: 10.1094/PHYTO-96-0437

This article is in the public domain and not copyrightable. It may be freely reprinted with customary crediting of the source. The American Phytopathological Society, 2006.
The family Luteoviridae currently includes not only 15 virus species in three genera (Luteovirus, Polerovirus, and Enamovirus) but also 11 unassigned members (11). These viruses are genetically diverse but collectively share several features clearly distinct from other plant viruses. These features include phloem restriction, transmission by aphids in a persistent circulative manner, lack of mechanical transmission, a high degree of vector specificity, host range restriction often to a single plant family, and serological relationships between most members of the family (46). The luteovirid genome contains five or six major open reading frames (ORF) referred to as ORF0 to ORF5 (12). Some luteovirids possess one to two additional ORFs $(7,48)$. The replicationassociated proteins encoded by ORF1 and ORF2 of members of the genus Luteovirus are phylogenetically related to those of viruses in the family Tombusviridae, whereas the ORF1 and ORF2 products of members of the genus Polerovirus and Enamovirus are strikingly similar to those of viruses in the genus Sobemovirus. This difference and variations in genomic organization are major criteria for assigning individual viruses to the genera of the family Luteoviridae (11).

Five luteovirids have so far been reported to infect faba bean and/or chickpea in different parts of the world, namely Bean leaf roll virus (BLRV) (6), BWYV (9,19), SbDV $(41,64)$, Pea enation mosaic virus-1 (PEMV-1) (13), and Chickpea stunt diseaseassociated virus $(\mathrm{CpSDaV})$. The latter has been reported only from India and is closely related to, but distinct from, BWYV $(53,56)$. It should be noted that virus isolates previously referred to as BWYV have been recently reclassified as four distinct virus species namely BWYV, Beet chlorosis virus, Beet mild yellowing virus (BMYV), and Turnip yellows virus (TuYV) on the basis of 
differences in host range and ORF0 sequences $(11,26,27)$. However, these viruses, which are referred to here as BWYV subgroup, are serologically closely related and cannot be distinguished readily by serological means $(27,59,61)$. The only available sequence information (ORF0 and ORF3) for a legume (faba bean) isolate of the BWYV subgroup (accession no. AF167478) indicates that it is more closely related to TuYV than to the other species of the BWYV subgroup (27). Although not known to infect faba bean and chickpea, two other luteovirids reported from legume crops are Indonesian soybean dwarf virus (ISDV) from soybean (31) and Groundnut rosette assistor virus (GRAV) from groundnut $(29,52)$.

Despite prevalence of luteovirids in faba bean and chickpea in countries such as Ethiopia and Morocco, their accurate identification has not been possible mainly due to the lack of specific antibodies or molecular detection tools $(2,17,18,28,43,45)$. Consequently, the identity of most luteovirids associated with legumes in the region has remained unknown. In this work, a previously unrecognized polerovirus was isolated from symptomatic chickpea and faba bean plants in Ethiopia in 2002 and characterized. Since field observation and greenhouse studies suggest that this virus causes most pronounced symptoms in chickpea, we propose the name Chickpea chlorotic stunt virus (CpCSV).

\section{MATERIALS AND METHODS}

Origin, initial serological analysis, and maintenance of virus isolates. Faba bean and chickpea plants showing yellowing and stunting symptom were collected from fields near Ambo, central Ethiopia. All samples were serologically analyzed in double (DAS) and triple (TAS) antibody sandwich enzyme-linked immunosorbent assay (ELISA) as described by Clark and Adams (10) and Franz et al. (20), respectively, using high-binding polystyrene plates (Greiner Bio-One GmbH, Germany) and the buffers described by Clark and Adams (10). In initial tests, samples were tested for the presence of luteovirids, nanoviruses, and the mastrevirus CpCDV using antibodies listed in Table 1. For detection of known luteovirids in the field samples from Ambo, specific anti- sera to PEMV-1 and SbDV were used in DAS-ELISA, whereas TAS-ELISA detection of BLRV and viruses of the BWYV subgroup was attempted using the monoclonal antibody (Mab) B-4-6G4 and the anti-TuYV MAbs T-4D3, -1E1, and -2G5, respectively (Table 1 ).

To establish luteovirid isolates in faba bean seedlings under greenhouse conditions, the aphid species Aphis craccivora Koch was used for vector transmission from one fresh sample each from faba bean and chickpea as described below. This was only successful for the faba bean isolate which, for the purpose of this paper, is referred to as CpCSV-FB. At intervals of about 6 weeks, CpCSV-FB was maintained in faba bean by aphid transmission. Isolates of BMYV, Potato leaf roll virus (PLRV), and TuYV were maintained in beet, Physalis floridana Rydb., and oilseed rape, respectively, using Myzus persicae (Sulzer) for vector transmission. Desiccated leaf tissues containing BLRV, CpCDV, and $\mathrm{SbDV}$ isolates were from the stock of the Federal Biological Research Center for Agriculture and Forestry (BBA, Braunschweig, Germany) and served as controls for TAS- and/or DASELISA experiments.

Total RNA extraction and reverse transcriptase-polymerase chain reaction amplification of the viral genome. Total RNA was extracted from dried and/or fresh leaf tissues of infected faba bean and chickpea using Nucleospin Plant Kit (Macherey-Nagel, Düren, Germany) following the manufacturer's instructions. For initial reverse transcriptase-polymerase chain reaction (RT-PCR) amplification of the capsid protein $(\mathrm{CP})$ gene, a pair of degenerate primers was derived from conserved domains in the CP genes of BWYV (NC_004756), TuYV (X13063), BMYV (X83110), Cucurbit aphid-borne yellows virus (CABYV; NC_003688), BLRV (NC_003369), and SbDV (NC_003056). The sense (5'GCTCTAGAATTGTTAATGARTACGGTCG-3') and antisense (5'-CACGCGTCIACCTATTTIGGRTTITG-3'; I = inosine) primers used include the start and stop codons, respectively, of the CP gene. A one-step RT-PCR was carried out in a 50- $\mu$ l reaction volume containing $5 \mu \mathrm{l}$ of $10 \times$ PCR buffer, $2.5 \mu \mathrm{l}$ of $50 \mathrm{mM} \mathrm{MgCl}$, $0.5 \mu \mathrm{l}$ of $100 \mathrm{mM}$ dNTPs, $1 \mu \mathrm{l}$ of each primer $(10 \mathrm{mM}), 1 \mu \mathrm{l}$ of Taq polymerase ( 5 units/ $\mu$ l, Invitrogen, Karlsruhe, Germany), and

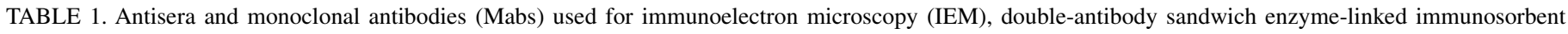
assay (DAS-ELISA), and/or triple-antibody sandwich (TAS)-ELISA

\begin{tabular}{|c|c|c|c|c|c|}
\hline \multirow[b]{3}{*}{ Antiserum to } & \multirow[b]{3}{*}{ Source and/or reference } & \multicolumn{4}{|r|}{ Antiserum used in } \\
\hline & & \multirow[b]{2}{*}{ IEM } & \multirow[b]{2}{*}{$\begin{array}{l}\text { DAS- } \\
\text { ELISA }\end{array}$} & \multicolumn{2}{|r|}{ TAS-ELISA } \\
\hline & & & & $\begin{array}{l}\text { As trapping } \\
\text { antibody }\end{array}$ & $\begin{array}{c}\text { With detecting antibody } \\
\text { [specificity, source (reference)] }\end{array}$ \\
\hline Bean leaf roll virus (BLRV) & Stock of BBA (33) & + & - & + & $\begin{array}{l}\text { Mab B-4-6G4 [raised against, and specific to, BLRV; } \\
\text { stock of BBA (33)] }\end{array}$ \\
\hline Beet mild yellowing virus & F. Rabenstein, Germany & + & - & - & \\
\hline 'BWYV'a & DSMZb AS-0049 & + & + & + & $\begin{array}{l}\text { Mab B-2-5G4 [raised against BLRV but reacting with } \\
\text { several luteovirids; stock of BBA (33)]; Mab 510H } \\
\text { [raised against a beet isolate of the BWYV subgroup } \\
\text { (15); identical to ATCC PVAS-647] }\end{array}$ \\
\hline Barley yellow dwarf virus-MAV & Stock of BBA (W. Huth) & + & - & - & \\
\hline Barley yellow dwarf virus-PAV & Stock of BBA (H. L. Paul) & + & - & - & \\
\hline Carrot red leaf virus & Stock of BBA (H. J. Vetten) & + & - & - & \\
\hline Chickpea chlorotic dwarf virus & Stock of BBA (H. J. Vetten) & - & + & - & \\
\hline Cereal yellow dwarf virus-RPV & Stock of BBA (W. Huth) & + & - & - & \\
\hline $\begin{array}{l}\text { Faba bean necrotic yellows virus } \\
\text { (FBNYV) }\end{array}$ & Stock of BBA (33) & - & - & + & $\begin{array}{l}\text { Mabs } 1-1 F 2,2-1 \mathrm{~A} 1 \text {, and } 3-4 \mathrm{~F} 2 \text { [raised against } \\
\text { FBNYV but reacting with many nanovirus species; } \\
\text { stock of BBA (20)] }\end{array}$ \\
\hline Groundnut rosette assistor virus & A. F. Murant, Dundee, UK & + & - & - & \\
\hline Pea enation mosaic virus- 1 & DSMZ ${ }^{\mathrm{b}}$ AS-0017 & + & + & - & \\
\hline Potato leaf roll virus & DSMZ ${ }^{\mathrm{b}}$ AS-0741 & + & + & - & \\
\hline Soybean dwarf virus & K. M. Makkouk, Syria & + & + & - & \\
\hline Turnip yellows virus (TuYV) & F. Rabenstein, Germany & + & + & + & $\begin{array}{l}\text { Mabs T-1E1, -2G5, and -4E3 [raised against TuYV } \\
\text { but reacting with most species of the BWYV } \\
\text { subgroup; F. Rabenstein, Germany] }\end{array}$ \\
\hline
\end{tabular}

\footnotetext{
a An unidentified species of the Beet western yellows virus (BWYV) subgroup ('BWYV').
}

b German Collection of Microorganisms and Cell Cultures. 
$0.05 \mu \mathrm{l}$ of AMV reverse transcriptase (300 units/ $\mu$, Promega, Mannheim, Germany) at a primer annealing temperature of $55^{\circ} \mathrm{C}$. RT-PCR amplification of the remaining internal parts of the genome was done by "primer walking" using combinations of a specific primer derived from a known genome part and a degenerate primer targeted to the unknown genome region.

Rapid amplification of cDNA ends procedures. Rapid amplification of complementary DNA (cDNA) ends (RACE) was used to determine the $3^{\prime}$ and $5^{\prime}$ ends of the CpCSV-FB genome as described (14) with minor modifications. For 3' RACE, viral RNA extracted from purified CpCSV-FB particles was polyadenylated to allow for amplification of the $3^{\prime}$ end of the genome with an oligo $\mathrm{d}(\mathrm{T})_{18}$ primer (5'-GCGGGATCCTTTTTTTTTTTTTTTTTT-3') using yeast poly(A) polymerase (Amersham, Freiburg, Germany) as described by the manufacturer. Synthesis of cDNA was done using oligo $\mathrm{d}(\mathrm{T})_{18}$, poly(A)-tailed RNA as template and M-MMLV transcriptase (Gibco) according to manufacturer's instructions. PCR was run with a sequence-specific sense primer (5'-CACCTATCCCAAAGGACAGCTTGT-3', nt 4861-4884) and the oligo $\mathrm{d}(\mathrm{T})_{18}$ primer.

For 5' RACE, cDNA was synthesized as described for 3' RACE but viral RNA was incubated with a sequence-specific antisense primer (5'-GTCGTACATATGCGCCAACGA-3', nt 514-534). By following the Nucleospin extract 2 in 1 protocol for direct purification of PCR products (Macherey-Nagel), the preparation was freed of excess primers and eluted. For end-tailing of the cDNA with poly $(\mathrm{C})$ residues, cDNA was incubated with terminal deoxynucleotidyl transferase (TdT) (25 units/ $\mu$ l, MBI Fermentas, St. Leon-Rot, Germany) and dCTP as described by the manufacturer. PCR was run using another internal sequence-specific antisense primer 5'-GTCGTACATATGCGCCAACGA-3', nt 460-480) and an anchoring homopolymeric poly(G) primer (5'-AACTGCAGAAGGGGGGGGGG-3') under conditions similar to those of $3^{\prime}$ RACE.

Cloning and sequence analysis. PCR products were purified from a $1 \%$ agarose gel using the Nucleospin Extract Kit (Macherey-Nagel), ligated into a pGEM-T vector (Promega) with T4 DNA ligase, and transformed by heat shock into DH5 $\alpha$ competent Escherichia coli cells essentially following the Promega protocol derived from Sambrook et al. (58). Extraction of plasmid DNA was done using the Nucleospin Plasmid Kits (MachereyNagel). DNA sequencing was performed by a commercial company (MWG Biotech, Ebersberg, Germany). Sequence assembly, multiple alignment, and identity analyses of nucleotide and amino acid sequences were carried out using the computer software DNAMAN (Lynnon Biosoft, Canada). The sequences were compared with available database sequences using the basic local alignment search tool (BLAST) program (5). Phylogenetic trees were reconstructed using neighbor joining algorithms in the ClustalX (version 1.83) program (66), after multiple alignment of sequences, and visualized using the Treeview program (55). GenBank accession numbers of virus sequences used in sequence comparison and/or phylogenetic analysis were as follows: Barley yellow dwarf virus-PAV (BYDV-PAV, D85783), Beet chlorosis virus (BChV, NC_002766), BLRV (NC_003369), BMYV (X83110), BWYV (NC_004756), CABYV (NC_003688), Carrot red leaf virus (CtRLV, NC 006265), Cereal yellow dwarf virus$R P V$ (CYDV-RPV; NC_004751), CpSDaV (Y11530), GRAV (AF195828), PEMV-1 (L04573), PLRV (D00734), SbDV (NC_003056), Sugarcane yellow leaf virus (ScYLV, NC_000874), Tobacco vein distorting virus (TVDV, AJ704890), and TuYV (X13063). Possible recombination events were tested using the default settings of the Sister scanning (SiScan) program (21) after aligning the entire nucleotide sequences of CpCSV-FB as a possible recombinant virus with those of CABYV and SbDV used as putative parents.

Vector transmission and host range studies. For vector transmission studies of CpCSV-FB, colonies of four common legume aphid species, namely Aphis craccivora, Aphis fabae Scopoli, and Acyrthosiphon pisum Harris each reared on faba bean and $M$. persicae maintained on radish, were used. Several hundred individuals of each species at different larval stages were given an acquisition access feeding period of $48 \mathrm{~h}$ on infected faba bean plants followed by an inoculation access feeding period of $48 \mathrm{~h}$ on young faba bean seedlings using about 30 individuals per plant. After spraying with an insecticide, the plants were kept in an insect-proof glasshouse and observed for symptom development. All inoculated plants were tested for virus infection by TAS-ELISA using Mab B-2-5G4 as described above. A similar experimental approach was used for determining the host range of CpCSV-FB. However, only Aphis craccivora was used for inoculating about 10 plants of each legume and nonlegume species. Both vector transmission and host range experiments were repeated three times.

Virus purification. CpCSV-FB was propagated in a local faba bean variety following vector inoculation of 1-week-old seedlings. Since CpCSV-FB induced mild symptoms in faba bean under greenhouse conditions, all plants were serologically analyzed using Mab B-2-5G4 in TAS-ELISA at 4 to 6 weeks after inoculation. The aboveground parts of all ELISA-positive plants were harvested, ground to a fine powder in liquid nitrogen with a Warring blender, and kept frozen at -20 or $-80^{\circ} \mathrm{C}$ until use. The amount of faba bean tissue typically used for virion purification was 300 to $500 \mathrm{~g}$. The purification protocol used was essentially based on the method of Takanami and Kubo (63) but omitted the use of macerating enzymes for virus extraction. An electron microscope (Zeiss EM906; Carl Zeiss Ag, Oberkochen, Germany) was used at a magnification of approximately $\times 36.000$ to examine virion preparations. Concentrations of CpCSV-FB virions were estimated by spectrophotometry assuming an extinction coefficient of $A_{260 \mathrm{~nm}}^{0.1 \%}=8.6$ (based on the value calculated for luteovirid particles [63]).

Production and characterization of poly- and monoclonal antibodies. A rabbit was given three intramuscular injections each of $\approx 50 \mu \mathrm{g}$ of CpCSV-FB virions at 2-week intervals. For the first injection, the virion preparation was emulsified with an equal volume of Freund's complete adjuvant (Difco Laboratories, Detroit), whereas Freund's incomplete adjuvant was used for the second and third injections. Starting 10 days after the last injection, the rabbit was bled biweekly from the lateral ear vein. Immunoglobulin $\mathrm{G}$ ( $\mathrm{IgG}$ ) isolation, labeling of $\operatorname{IgG}$ with alkaline phosphatase (Roche, Germany), and DAS-ELISA were conducted as described (10).

For Mab production, each of three female Balb/c mice (2 to 3 months old) received a subcutaneous injection of $100 \mu \mathrm{l}$ containing $\approx 20 \mu \mathrm{g}$ of CpCSV-FB virions (and 50\% Freund's incomplete adjuvant). Booster injections, fusion experiments, selection of hybridomas, and cloning were essentially conducted as described $(3,21)$. However, IgG to CpCSV-FB was used as coating antibody in TAS-ELISA for the trapping of antigen from CpCSVFB-infected and noninoculated faba bean. Isotyping of Mabs was done using the Hbt Mouse Monoclonal Antibody Isotyping Kit (HyCult Biotechnology, the Netherlands) essentially following the manufacturer's instructions. Serial dilutions of culture supernatants ranging from $1: 10$ to $1: 256,000$ were tested in TASELISA for determining Mab titers.

Immunoelectron microscopy. Immunosorbent electron microscopy (ISEM) and immunoelectron microscopy (IEM) decoration titer experiments with purified CpCSV-FB virions or extracts from luteovirid-infected leaves were done as described $(50,51)$, using the antisera listed in Table 1 . To reveal weak decoration reactions of Mabs with CpCSV-FB virions, colloidal gold $(\varnothing 5 \mathrm{~nm})$ coated with rabbit anti-mouse IgG (British Biocell International, Cardiff, UK) was used essentially as described (3).

Sodium dodecyl sulfate-polyacrylamide gel electrophoresis and western blot analysis. The $\mathrm{CP}$ size of $\mathrm{CpCSV-FB}$ virions 
was determined by sodium dodecyl sulfate-polyacrylamide gel electrophoresis (SDS-PAGE) analysis of a purified virion preparation using a $4 \%$ stacking gel on a $12 \%$ resolving gel and the buffer system of Laemmli and Favre (36). Proteins were stained with $0.2 \%$ (wt/vol) Coomassie brilliant blue. Purified virions as well as extracts from infected and noninfected faba bean plants were used for testing the ability of each Mab to react with CpCSV-FB antigen in western blots (69).

\section{RESULTS}

First serological and molecular evidence for a new luteovirid. When symptomatic chickpea and faba bean samples from Ambo, Ethiopia were serologically analyzed, many of them reacted only with Mab B-2-5G4, a broad-spectrum luteoviridspecific Mab, but not with poly- and monoclonal antibodies to CpCDV and FBNYV in DAS- and TAS-ELISA, respectively. In attempts to identify the virus, specific antibodies to BLRV, PEMV-1, SbDV, and viruses of the BWYV subgroup also failed to react with the samples (data not shown). Since this suggested the possible occurrence of an unknown or uncommon luteovirid, degenerate luteovirid primers were used in an attempt at RT-PCR amplification of the CP sequence of this virus. RT-PCR yielded an amplicon of the expected size $(\approx 600 \mathrm{bp})$ from several ELISA (Mab B-2-5G4)-positive samples. Cloning and sequencing of the amplicon from a chickpea and a faba bean sample indicated that the two isolates share $\mathrm{CP}$ nucleotide sequence identities of $96 \%$. Also, the alignment of the deduced CP amino acid sequences of the two isolates revealed an identity of $97.5 \%$, indicating they are isolates of the same virus species that differ only in 3 of the 200 amino acid residues that potentially form the CP of this virus. BLASTP search using the deduced amino acid sequence revealed striking similarities with luteovirid $\mathrm{CP}$ sequences. Based on $\mathrm{CP}$ sequences, this new virus appeared to be most closely related (78\%) to GRAV followed by several poleroviruses (Table 2).

Sequence analysis of the CpCSV genome. For assigning the new virus to a genus of the family Luteoviridae, its complete nucleotide sequence was determined. The genomic RNA of CpCSVFB was 5,900 nts long with a genomic organization similar to poleroviruses (Fig. 1). The 5' untranslated region (UTR) of the CpCSV-FB RNA consisted of 50 nts with the first 8 nts (ACAAAAGA) being identical to those of other poleroviruses, such as BMYV, BWYV, CABYV, and PLRV. The 3' UTR of the CpCSV-FB genome was 177 nts in length ending in the hexanucleotide CGGTGT, which is also conserved in BMYV, BWYV, and CABYV. The intergenic region between the CpCSV-FB ORF2 and ORF3 was 192 nts. A few bases upstream of the start of the intergenic region, the CPCSV-FB genome contained a perfect copy of the $5^{\prime}$ consensus sequence ACAAAA, which has been shown to be the start site of the subgenomic RNA1 (sgRNA1) of PLRV and BWYV $(47,57)$.
ORF0 (nt 51 to 860) of CpCSV-FB potentially encodes a protein (P0) of $30.8 \mathrm{kDa}$ (Fig. 1), which shares very low but significant similarities with the P0 of CABYV (21.5\%) and other poleroviruses $(\approx 20 \%$ ) (Table 2). ORF1 (nt 190 to 2190) of CpCSV-FB codes for a 73.9-kDa protein (P1; Fig. 1) homologous to and most closely related to both TuYV and CABYV $(\approx 30 \%)$ and other poleroviruses $(\approx 28 \%$ ) (Table 2$)$. Since this protein contains the serine protease motif HX29-34 [D/E]X62-63TXKGYSG $(22,34)$, it appears to have a protease function analogous to that of other poleroviruses. A sequence similar to the N-terminal part of the virus genome-linked protein described for PLRV (67) can be mapped to amino acids 411 to 442 in the P1 of CpCSV-FB. ORF2 (nt 1728 to 3467 ) encoding a putative RNA-dependent RNA polymerase (P2) with a predicted molecular mass of $66.5 \mathrm{kDa}$ overlaps ORF1 by 463 nts (Fig. 1). This protein is expressed as a fusion protein from ORF1 by -1 frameshift with two features, a slippery heptanucleotide site and a secondary structure needed to promote efficient frameshifting (48). The putative frameshifting slippery heptamer of CpCSV-FB has the canonical sequence UUUAAAC (nt 1728 to 1734) (48). However, this heptanucleotide is different from that of any other luteovirid but identical to a shifty sequence of the sobemovirus Cocksfoot mottle virus (CfMV) (38), further supporting the close evolutionary relationship of sobemoviruses and poleroviruses in this genome part. The slippery sequence is followed after six bases by a sequence that could potentially form a pseudoknot structure. The core RNA polymerase motif GXXXTXXXN(X25-40)GDD present in RNAdependent RNA polymerases of plus-strand RNA viruses (32) mapped to amino acids 450 to 480 of the CpCSV-FB P2. This protein shares amino acid sequence identities of $\approx 70 \%$ with nearly all poleroviruses (Table 2), confirming that the polerovirus $\mathrm{P} 2$ is highly conserved. The ORF1-ORF2 fusion protein of CpCSV-FB is phylogenetically most closely related to that of other poleroviruses but clearly distinct from that of PEMV-1 and the luteoviruses BYDV-PAV, BLRV, and SbDV (Fig. 2A).

ORF3 (nt 3663 to 4262) of CpCSV-FB encodes the CP (22 kDa) (Fig. 1), which is most similar to that of GRAV (78\%) followed

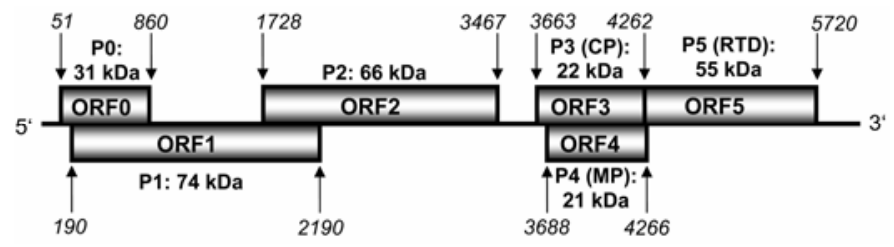

Fig. 1. Schematic representation of the organization of the Chickpea chlorotic stunt virus (CpCSV) genome. Gray rectangles indicate the major open reading frames (ORFs) (ORF0 to ORF5) predicted for the CpCSV RNA. The name and deduced size of the individual gene products are given above or below each $\mathrm{ORF}(\mathrm{CP}=$ coat protein; $\mathrm{MP}=$ movement protein; and $\mathrm{RTD}=$ readthrough domain). The exact nucleotide position of the beginning and the end of each ORF is indicated.

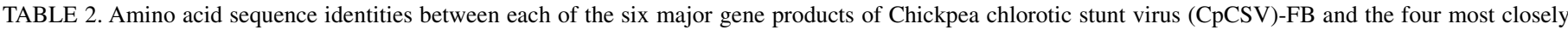
related homologous proteins of other luteovirid species ${ }^{\mathrm{a}}$

\begin{tabular}{|c|c|c|c|c|c|c|c|c|c|c|c|c|}
\hline \multirow{2}{*}{$\begin{array}{l}\text { Relative } \\
\text { order }^{b}\end{array}$} & \multicolumn{2}{|c|}{$\mathrm{P} 0$} & \multicolumn{2}{|c|}{$\mathrm{P} 1$} & \multicolumn{2}{|c|}{$\begin{array}{l}\text { P2 (RNA-dependent } \\
\text { RNA polymerase) }\end{array}$} & \multicolumn{2}{|c|}{ P3 (coat protein) } & \multicolumn{2}{|c|}{$\begin{array}{c}\mathrm{P} 4 \\
\text { (movement protein) }\end{array}$} & \multicolumn{2}{|c|}{ P5 (readthrough domain) } \\
\hline & Virus & Identity & Virus & Identity & Virus & Identity & Virus & Identity & Virus & Identity & Virus & Identity \\
\hline 1 & CABYV & 21.5 & TuYV & 30.2 & BWYV & 71.7 & GRAV & 77.9 & CABYV & 59.7 & CABYV & 53.4 \\
\hline 2 & BMYV & 20.6 & CABYV & 29.2 & BMYV & 70.5 & CABYV & 71.7 & TuYV & 48.9 & PEMV-1 & 46.5 \\
\hline 3 & TuYVc & 20.2 & CtRLV & 27.7 & CABYV & 70.0 & TuYVc & 69.5 & BWYV & 48.8 & BLRV & 27.7 \\
\hline 4 & BWYV & 19.4 & BMYV & 27.6 & TuYV & 70.0 & $\mathrm{CpSDaV}$ & 68.2 & $\mathrm{BChV}$ & 47.7 & SbDV & 24.5 \\
\hline
\end{tabular}

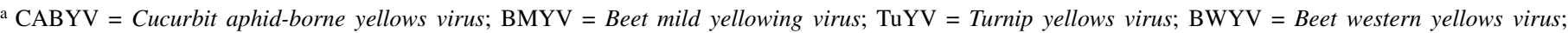

$\mathrm{CtRLV}=$ Carrot red leaf virus; GRAV = Groundnut rosette assistor virus; $\mathrm{CpSDaV}=$ Chickpea stunt disease-associated virus $;$ PEMV-1 = Pea enation mosaic virus $-1 ; \mathrm{BChV}=$ Beet chlorosis virus $; \mathrm{BLRV}=$ Bean leaf roll virus $;$ and $\mathrm{SbDV}=$ Soybean dwarf virus .

${ }^{\mathrm{b}}$ Only the four luteovirid species most closely related to CpCSV-FB in one of the six major gene products of poleroviruses are listed.

c This TuYV isolate was formerly referred to as BWYV-FL1 (68). 
by that of poleroviruses, such as CABYV (72\%), TuYV (70\%), CpSDaV (68.2\%), PLRV (65\%), and CYDV-RPV (60\%) (Table 2; Fig. 2B). Species of the genus Luteovirus, such as BLRV, SbDV, and BYDV-PAV, shared CP amino acid identities of only 59, 57, and $44 \%$, respectively, with CpCSV (Fig. 2B). Unlike most luteovirids whose ORF4 is completely embedded within ORF3, the CpCSV-FB ORF4 (nt 3688 to 4266) extends few bases beyond the CP gene termination codon (nt 4262 to 4264) (Fig. 1). Only GRAV (60) and CABYV (24) have a similar arrangement of ORF4 in relation to ORF3. Consequently, the predicted ORF4 product of these three viruses is slightly larger (by about 18 amino acids when compared with BWYV) than that of other luteovirids. The P4 of CpCSV-FB was most closely related to the corresponding proteins of CABYV $(60 \%)$ and viruses of the BWYV subgroup ( $\approx 48 \%$ ) (Table 2 ).

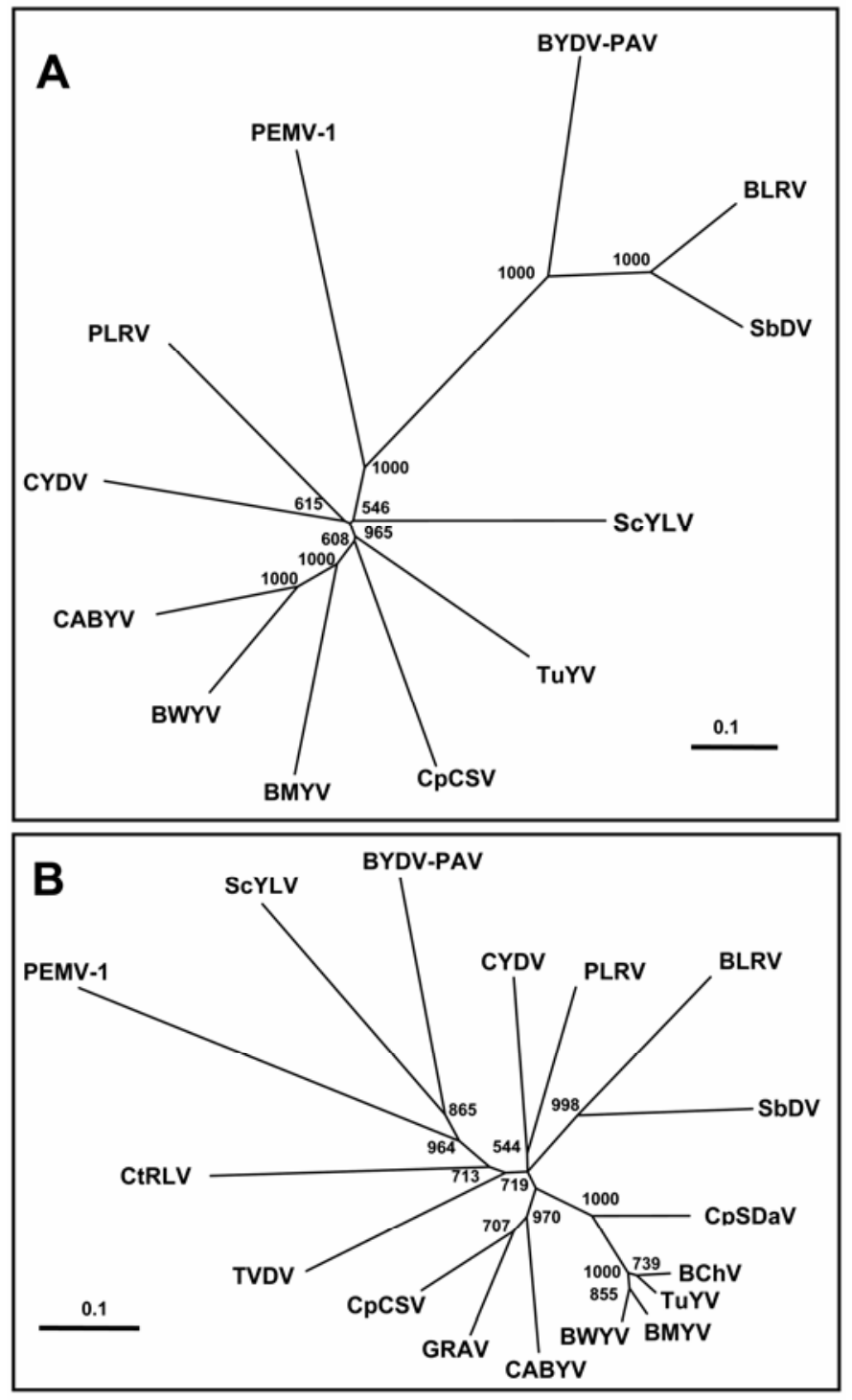

Fig. 2. Phylogenetic relationships between Chickpea chlorotic stunt virus (CpCSV) and other luteovirids on the basis of the amino acid sequences of $\mathbf{A}$, the open reading frame (ORF)1-ORF2 fusion protein and $\mathbf{B}$, the coat protein. Multiple sequence alignments were generated using the ClustalX program (version 1.83; default parameters) and phylogenetic trees were constructed by the neighbor-joining method, based on calculations from pairwise amino acid sequence distances for protein analyses derived from the multiple alignment format. The branch lengths are proportional to the genetic distance (the scale bar indicates the number of substitutions per amino acid residue). The numbers at each node indicate the bootstrap values resulting from 1,000 bootstrap replicates. Only bootstrap scores higher than 500 are shown.
The CpCSV-FB ORF5 (nt 4262 to 5720) is separated from ORF3 by an amber termination codon and potentially codes for an ORF3-ORF5 fusion (readthrough) protein (P5) of $77 \mathrm{kDa}$ (Fig. 1). Although most parts of the CpCSV-FB genome and particularly its $3^{\prime}$ half were closely related to CABYV (Fig. 2B; Table 2), a stretch of about 90 amino acids in the C-terminal part of its P5 readthrough domain (RTD) was strikingly different (identity of $18 \%$ ) from CABYV but shared identities of 58 and $40 \%$ with a corresponding P5 RTD domain of SbDV and BLRV, respectively (data not shown). Recombination analysis of the entire CpCSVFB genome using the SiScan program (21) gave strong support for recombination ( $\mathrm{Z}$ value $>3$ ) at this RTD site (Fig. 3).

Vector transmission and specificity. In three transmission experiments using acquisition and inoculation access feeding periods each of $48 \mathrm{~h}$, only plants that were inoculated using Aphis craccivora that had been given prior access to CpCSV-FBinfected faba bean plants developed virus symptoms 2 to 3 weeks after inoculation and reacted with Mab B-2-5G4. None of the plants inoculated with Acyrthosiphon pisum, Aphis fabae, or $M$. persicae fed on CpCSV-FB-infected plants developed symptoms or became ELISA-positive. This indicated that, of the four aphid species tested, only Aphis craccivora is a vector of the new virus.

Experimental host range and symptomatology. Of the 21 different plant species inoculated with CpCSV-FB using Aphis craccivora as vector, only four legume species (Vicia faba, Cicer arietinum, Lens culinaris, and Pisum sativum) were infected. Symptoms caused by CpCSV-FB in faba bean and chickpea included a slight stunting with yellowing and veinal chlorosis most pronounced at the margins of older leaves. In general, symptoms in chickpea and, particularly, in faba bean were less severe under glasshouse conditions than those observed in the original plants under field conditions in Ethiopia probably due to differences in environmental conditions or plant cultivars. Infected lentil plants showed a striking yellowing, reddening and stunting, with smaller and distorted leaves. In pea plants, infections appeared to be latent, as all plants were ELISA-positive but failed to produce symptoms in the greenhouse. Despite repeated inoculation attempts (three independent experiments), the virus was not detected in all other legume species tested, including Arachis hypogaea L., Glycine max (L.) Merr., Medicago sativa L., Phaseolus lunatus L., Phaseolus radiata L., Phaseolus vulgaris L., Vigna subterranea (L.) Verdc, and Vigna unguiculata (L.) Walp. All

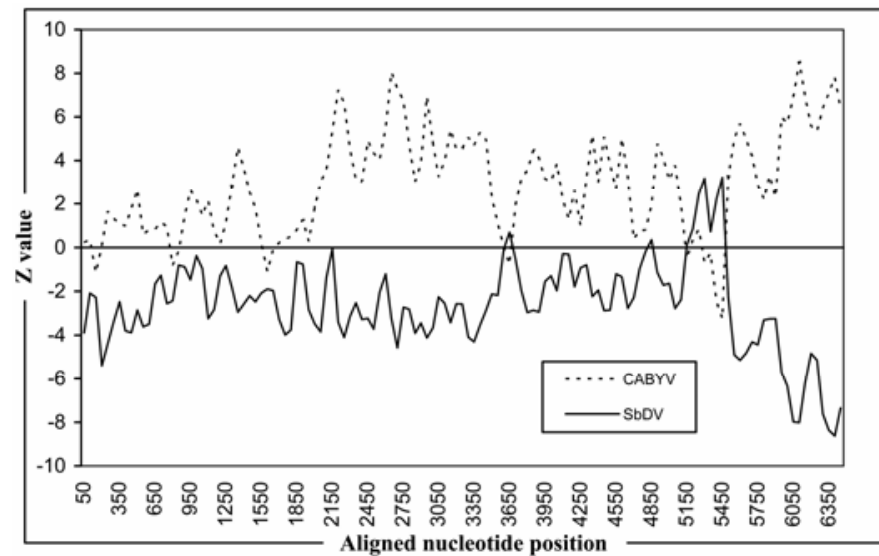

Fig. 3. Graph showing the result of the recombination analysis of aligned luteovirid genome sequences using the Sister scanning procedure. The complete nucleotide sequence of Chickpea chlorotic stunt virus (CpCSV)-FB was compared with those of Cucurbit aphid-borne yellows virus (CABYV) (dashed line) and Soybean dwarf virus (SbDV) (solid line). Z score values greater than 3 strongly suggest a close phylogenetic relationship to a certain virus (21). Note that peaks at nucleotide position 5300 and 5400 have $\mathrm{Z}$ score values of greater than 3 . 
nonlegume species tested, Beta vulgaris L., Coriandrum sativum L., Chenopodium amaranticolor Coste \& Reyn, Chenopodium quinoa Willd, Lactuca sativa L., Nicotiana benthamiana Domin., N. clevelandii Gray, Physalis floridana, and Raphanus sativus L. var. niger (Mill.) S. Kerner, were not hosts of the virus.

Morphology and physicochemical properties of purified virions. Purified CpCSV-FB virions sedimented as a single component in sucrose density gradients when gradient fractions were analyzed using an absorbance monitor (ISCO Model UA-5, ISCO, Lincoln, NE). Electron microscopy revealed numerous isometric particles measuring about $28 \mathrm{~nm}$ and having a smooth surface and a slightly hexagonal outline (Fig. 4A). The yield of purified virions from infected faba bean plants ranged from 150 to $250 \mu \mathrm{g}$ per $\mathrm{kg}$ of tissue. SDS-PAGE analysis of purified virions gave a strong and a faint protein band, with $\mathrm{Mr}$ values of $\approx 20 \times$ $10^{3}$ and $50 \times 10^{3}$, corresponding to the major $\mathrm{CP}$ and the presumably proteolytically degraded (23) readthrough protein, respectively (Fig. 4B).

Serological relationships. When the antiserum to CpCSV-FB was used in DAS-ELISA, strong homologous reactions were observed using trapping IgG and enzyme-labeled antibodies at concentrations of $1 \mu \mathrm{g} / \mathrm{ml}$ and 1:1,000, respectively. Under these DAS-ELISA conditions, the CpCSV-FB antiserum did not react with extracts from BLRV-, PEMV-1-, PLRV-, and SbDV-infected plants, but reacted weakly with those from BMYV- and TuYVinfected plants (data not shown). In reciprocal DAS-ELISA experiments, antisera to 'BWYV' and TuYV (Table 1) gave weak and intermediate reactions, respectively, with CpCSV-FB, whereas antisera to BLRV, PEMV, SbDV, and PLRV (Table 1) produced strong homologous reactions but failed to react with CpCSV-FB and in any other heterologous combinations (data not shown). Similarly in TAS-ELISA, the Mabs T-1E1, -2G5, and -4D3 raised against TuYV reacted only with TuYV and BMYV, but not with CpCSV-FB and any of the other viruses tested. In contrast, Mab $510 \mathrm{H}$ raised against an isolate of the BWYV subgroup gave not only very strong reactions with BMYV and TuYV but also an intermediate reaction with CpCSV-FB (data not shown).

To substantiate the ELISA data, IEM experiments were conducted. The CpCSV-FB antiserum strongly decorated purified virions of CpCSV-FB. When assessing the serological relationship of CpCSV to other viruses in IEM, purified CpCSV-FB virions were not decorated when antisera to BYDV-MAV, BYDVPAV, BLRV, CtRLV, PEMV, and SbDV were used at 1:50 dilutions. Whereas antisera to CYDV-RPV, GRAV, and PLRV only decorated CpCSV-FB virions slightly, a strong decoration was observed with the antiserum to 'BWYV', BMYV, and TuYV (data not shown). To study the apparent close serological relationship between CpCSV and virus species of the BWYV subgroup, antisera to CpCSV-FB, 'BWYV', BMYV, and TuYV were used for IEM decoration titer experiments in various combinations. Following overnight trapping (ISEM) of virions from CpCSV-FBand TuYV-infected faba bean and oilseed rape plants, respectively, all antisera had similar homologous titers $(1: 3,200$ or $1: 6,400)$. However, the homologous and heterologous titers of the antisera tested differed by only one to three dilution steps (Table 3).

Properties of Mabs. Since the CpCSV-FB antiserum crossreacted with virus species of the BWYV subgroup and thus appeared unsuitable for CpCSV identification, attempts were made to raise CpCSV-specific Mabs. From two fusion experiments, 10 stable hybridoma lines secreting antibodies specific to CpCSV-FB were obtained. Five, four, and one of the Mabs were unequivocally typed as IgG1, IgG2a, and IgG2b, respectively (Table 4), confirming the monoclonality of the antibodies. The Mabs gave intermediate to strong reactions with CpCSV-FB (Table 4). To confirm the CpCSV specificity of the Mabs, they were used for IEM decoration and western blot experiments. However, a visible decoration reaction with purified CpCSV-FB virions was not readily produced with any of the Mabs. When immunogold labeling was used for revealing weak decoration reactions of Mabs with CpCSV-FB virions, only Mabs 1-3D5 and 2-3D4 were shown to bind to virions ( $>50 \%$ of virions had two to three gold spheres). Immunogold labeling of the CpCSV-FB particles with the other eight Mabs either produced insignificant numbers $(<25 \%)$ of gold-labeled particles or none at all (Table 4$)$. In

TABLE 3. Homologous and heterologous decoration titers observed in immunoelectron microscopy of Chickpea chlorotic stunt virus (CpCSV)-FB and Turnip yellows virus (TuYV) virions following incubation with 1:50 to $1: 12,800$ dilutions of the antisera to the isolate CpCSV-FB, unidentified species of the Beet western yellows virus ('BWYV') subgroup, Beet mild yellowing virus (BMYV), and TuYV

\begin{tabular}{lllll}
\hline & \multicolumn{4}{c}{ Antiserum to } \\
\cline { 2 - 5 } Virions of ${ }^{\mathrm{a}}$ & CpCSV-FB & 'BWYV' & BMYV & TuYV \\
\hline CpCSV-FB & $\mathbf{1 : 6 , 4 0 0}{ }^{\mathrm{b}}$ & $1: 800$ & $1: 800$ & $1: 3,200$ \\
TuYV & $1: 1,600$ & $1: 6,400$ & $1: 3,200$ & $\mathbf{1 : 6 , 4 0 0}$ \\
\hline
\end{tabular}

a A mixture of the 'BWYV' and CpCSV-FB antisera was used for overnight trapping (immunosorbent electron microscopy) of virions from CpCSV-FBand TuYV-infected faba bean and oilseed rape plants, respectively.

${ }^{\mathrm{b}}$ Highest dilution of antiserum that gave a visible decoration for the indicated combinations. Homologous combinations are in bold.

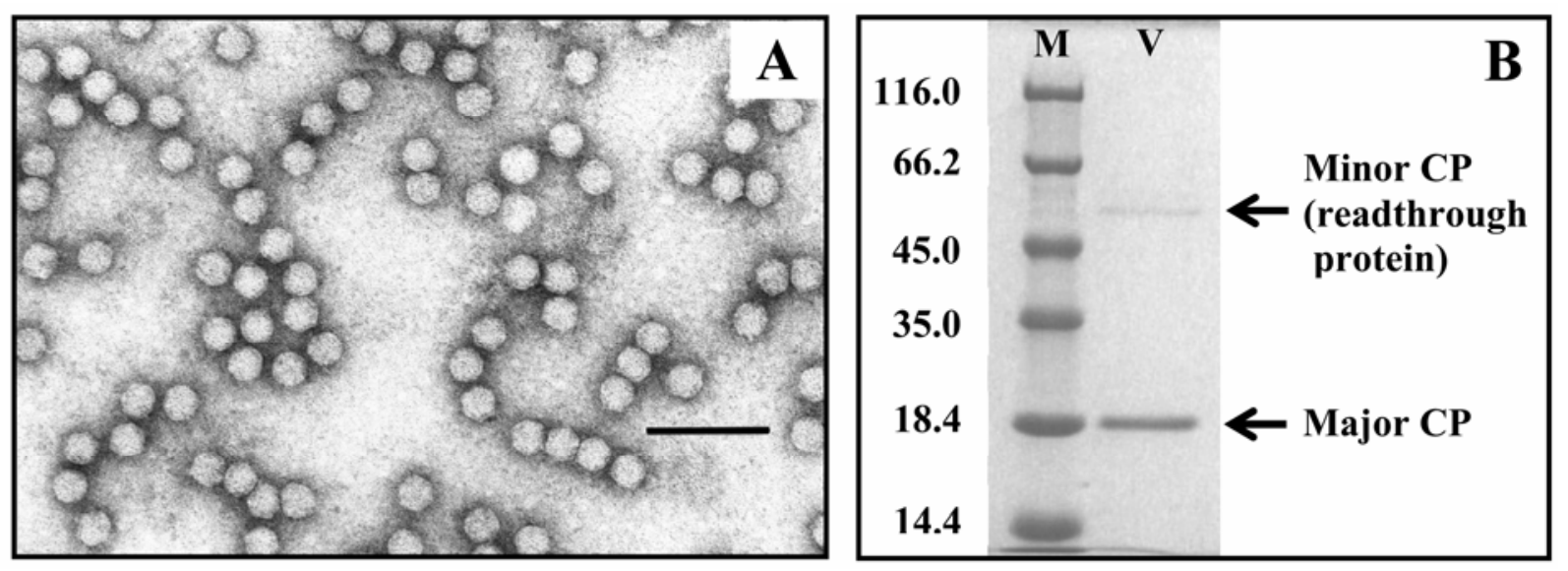

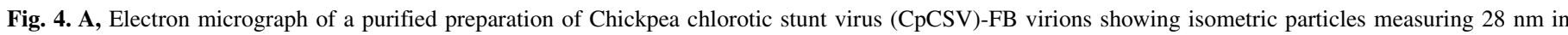

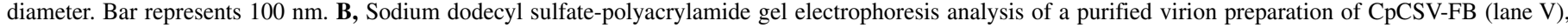

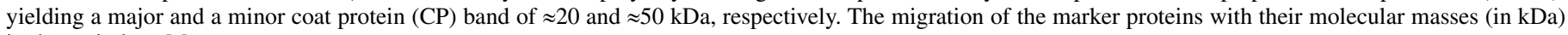
is shown in lane $M$. 
contrast to the polyclonal antibodies used as a control, none of the Mabs gave a western blot reaction following SDS-PAGE analysis of purified CpCSV-FB virions (data not shown).

There were striking differences in the titers of the Mab-containing culture supernatants (Table 4). For routine use in TAS-ELISA, culture supernatant dilutions of 1:50 to 1:250 were found to give the best signal to noise ratio. All the Mabs reacted only with the homologous antigen but not with any of the taxonomically related viruses (BLRV, BMYV, PEMV, PLRV, SbDV, and TuYV) in TAS-ELISA. When the 10 Mabs were individually tested for their ability to react with $\mathrm{CpCSV}$ in legume samples from various production areas of central Ethiopia, CpCSV was detected not only in 22 faba bean, 24 chickpea, and two lentil samples but also in two grasspea (Lathyrus sativum L.) and two fenugreek (Trigonella foenum-graecum $\mathrm{L}$.) samples by each of the $10 \mathrm{Mabs}$. Of the 10 Mabs, 1-1G5, 1-3H4, and 1-4B12, which gave stronger reactions consistently in various tests, were selected for routine use as detecting antibodies in TAS-ELISA. Use of the polyclonal IgG to CpCSV-FB as capture antibody and the Mabs as detecting antibodies permitted more sensitive detection of CpCSV antigen in TAS-ELISA than the use of the polyclonal antibodies alone in DAS-ELISA (data not shown).

\section{DISCUSSION}

Virus surveys of legume crops in several countries of West Asia and North Africa (WANA) have provided serological evidence for the occurrence of a range of viruses $(8,40,44)$. Whereas some of these viruses could be readily identified, the identity of others remained obscure due to the lack of specific diagnostic tools $(2,17,18,28,43,45)$. This problem has been particularly critical in studies on the etiology of the yellowing and stunting diseases of legume crops, which are generally thought to be caused by phloem-restricted viruses, such as mastreviruses, nanoviruses, and luteovirids, in WANA countries, including Ethiopia (44).

In attempts to identify the causal agent(s) of yellowing and stunting symptoms in faba bean and chickpea plantings near Ambo, Ethiopia, samples were collected and analyzed by serological means. Here the use of the 'BWYV' antiserum as capture antibody and the broad-spectrum luteovirid-specific Mab B-2-5G4 as detecting antibody was a serendipitous combination, as only this combination gave strong TAS-ELISA reaction with the unknown virus and, thus, provided serological evidence for a luteovirid infection in the samples studied. However, the use of specific antibodies to some luteovirids in ELISA gave no indications for the presence of BLRV-, PEMV-, SbDV-, and BWYV-like viruses in these samples, although these viruses (especially the latter) have been reported to occur frequently in legume crops in WANA countries (45).
Cloning and sequencing of RT-PCR products from Mab B-25G4-positive chickpea and faba bean samples led to the determination of a $\mathrm{CP}$ gene sequence that differs clearly from that of other legume-infecting polero- and luteoviruses (Fig. 2B). Since CP phylogeny shows the closest relationship of CpCSV to GRAV, for which only the CP gene sequence is available (60), CpCSV may also be most similar to GRAV in genome parts other than the $\mathrm{CP}$ gene. Based on the current criteria for species demarcation in the family Luteoviridae (11), CpCSV can be considered a distinct species as it differs by more than $10 \%$ in the amino acid sequence of any gene product and possesses distinctive serological and biological properties. The two genes widely used in luteovirid taxonomy are those coding for the $\mathrm{CP}$ and replication-associated proteins, whereby the latter are currently used as a primary criterion for assigning virus species (including recombinant viruses) to a genus in the family Luteoviridae (11). Phylogenetic trees based on both $\mathrm{CP}$ (Fig. 2B) and ORF1-ORF2 fusion protein sequences (Fig. 2A) placed CpCSV in close proximity to poleroviruses such as CABYV and viruses of the BWYV subgroup. Moreover, the arrangement and nucleotide sequences of the genes in the $5^{\prime}$ half of the $\mathrm{CpCSV}$ genome resemble those of polerovirus genomes (Table 2) whose $5^{\prime}$ half possibly originated from sobemovirus-like ancestors (11). Although CpCSV is a possible recombinant virus in a small part of its readthrough protein, it closely resembles poleroviruses in genome organization and phylogenetic relationships and presumably employs polerovirus-like replication and expression strategies. Therefore, we propose CpCSV to be considered a definitive member of genus Polerovirus of the family Luteoviridae.

Our evidence for a recombination event in the P5 RTD of CpCSV-FB is based not only on the results of the SiScan method (Fig. 3) but also on the observation that CpCSV-FB was most similar to poleroviruses in its $\mathrm{P} 0, \mathrm{P} 1, \mathrm{P} 2, \mathrm{P} 3$, and $\mathrm{P} 4$ sequences, whereas the luteoviruses BLRV and SbDV were among the closest relatives of CpCSV-FB only when the P5 RTD sequences were compared (Table 2). The RTD site where a possible recombination event has occurred in the CpCSV-FB genome is proposed to be an sgRNA2 start site by analogy to PLRV and CABYV (7). This is in agreement with the model of Miller and Mayo (47) and Miller et al. $(47,49)$ and with observations for BChV isolates $(26)$, indicating that the sgRNA2 start site of luteovirids might be a recombination hot spot. Therefore, we conclude that CpCSV-FB is a recombinant virus with most of its genome originating from a CABYV-like (or possibly GRAV-like) ancestor that has acquired an RTD fragment from an SbDV-like ancestor.

In addition to the molecular properties, we also provide biological and physicochemical evidence for the occurrence of a new polerovirus infecting cool-season food legumes in Ethiopia. Our attempts to biologically characterize CpCSV-FB concentrated on

TABLE 4. Properties of monoclonal antibodies (Mab) to the polerovirus isolate Chickpea chlorotic stunt virus (CpCSV)-FB

\begin{tabular}{|c|c|c|c|c|c|}
\hline Mab code & $\begin{array}{l}\text { Immunoglobulin } G \\
\text { (IgG) subtype }\end{array}$ & $\begin{array}{c}\text { Reciprocal titer } \\
\text { of culture supernatant }\end{array}$ & $\begin{array}{l}\text { TAS-ELISA } \\
\text { reaction strength }\end{array}$ & IEM decoration $^{\mathrm{b}}$ & Western blot reaction $^{\mathrm{c}}$ \\
\hline $1-1 \mathrm{G} 7$ & IgG1 & $>256,000$ & +++ & - & - \\
\hline $1-2 \mathrm{H} 4$ & IgG1 & $>256,000$ & +++ & - & - \\
\hline $1-3 \mathrm{D} 5$ & IgG1 & $>256,000$ & +++ & + & - \\
\hline $1-3 \mathrm{H} 4$ & $\operatorname{IgG} 2 b$ & $>256,000$ & +++ & - & - \\
\hline $1-4 \mathrm{~B} 12$ & IgG2a & $>256,000$ & +++ & - & - \\
\hline $2-1 B 4$ & $\operatorname{IgG} 2 \mathrm{a}$ & 256,000 & ++ & - & - \\
\hline $2-2 \mathrm{C} 1$ & $\operatorname{IgG} 2 \mathrm{a}$ & 1,600 & ++ & - & - \\
\hline $2-2 C 9$ & IgG1 & 800 & ++ & - & - \\
\hline $2-3 \mathrm{D} 4$ & IgG1 & $>256,000$ & ++ & + & - \\
\hline 2-6B10 & IgG2a & 32,000 & ++ & - & - \\
\hline
\end{tabular}

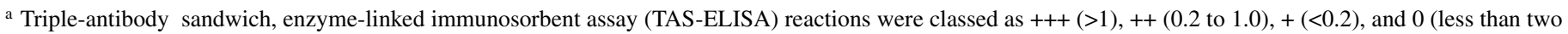
times the $A_{405 \mathrm{~nm}}$ value for the noninfected control).

${ }^{\mathrm{b}} \mathrm{IEM}=$ immunoelectron microscopy; + and - indicate whether a significant immunogold labeling of CpCSV-FB virions was observed or not, respectively.

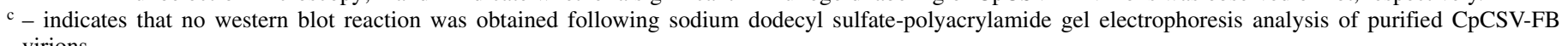
virions. 
identifying its aphid vector(s) and determining its experimental and natural host range. Of the four aphid species tested, only Aphis craccivora transmitted CpCSV-FB, suggesting a high level of vector specificity as is commonly observed for luteovirids (24). Since Aphis craccivora has been reported frequently from legume crops in Ethiopia (4), this aphid species also appears capable of acting as efficient vector of CpCSV under field conditions. The only other luteovirids primarily vectored by Aphis craccivora are GRAV and $\mathrm{CpSDaV}$, which have been reported from sub-Saharan Africa $(52)$ and India $(53,56)$, respectively. In addition to sharing the same vector species and being most closely related to each other in CP amino acid sequences, GRAV and CpCSV may also have overlapping geographical distributions in Africa. Naidu et al. (52) suggested that the groundnut rosette disease agents including GRAV have evolved with other plants in Africa and later infected groundnut when it was introduced in the 16th century. Therefore, it would be conceivable that the two viruses have a common ancestor in Africa from which they have diverged by adaptation to different legume hosts. Aphis craccivora is thought to have originated in the Mediterranean Basin (25) and has likely played an important role in the evolution of both GRAV and CpCSV.

Since only 4 of the 12 legume species and none of the nine nonlegume species tested became infected with CpCSV-FB under experimental conditions, this virus appears to have a narrow host range. Our serological analysis of field samples using CpCSVFB-specific Mabs not only confirmed that chickpea and faba bean are natural hosts of CpCSV but also indicated that lentil, grasspea, and fenugreek, three other important legume crops in Ethiopia (65), are also naturally infected with CpCSV. The latter observation was corroborated by sequence analysis of RT-PCR products obtained from lentil, grasspea, and fenugreek samples (A. D. Abraham, M. Varrelmann, and H. J. Vetten, unpublished data). With the exception of groundnut, the natural and experimental host range of CpCSV-FB was indistinguishable from that of CpSDaV, with which CpCSV-FB also shares the same aphid vector species (56). Unlike GRAV whose only known natural host is groundnut (52), CpCSV-FB did not infect groundnut but only a limited number of cool-season food legumes, which with the exception of Pisum sativum, are not hosts of GRAV (29). In contrast, CABYV, the other close CpCSV relative from the Mediterranean Basin, is vectored primarily by $M$. persicae and predominantly infects cucurbits (37).

Since the differences in CP amino acid sequences between CpCSV and luteovirids other than those of the BWYV subgroup range from 22 to $58 \%$, it was not surprising that nearly all antisera to these luteovirids did not decorate (or only weakly decorated) CpCSV-FB virions in IEM and the majority of the mono- and polyclonal antibodies raised against other luteovirids did not cross-react with CpCSV-FB in ELISA. On the other hand, the obvious cross-reactions between CpCSV-FB and viruses of the BWYV subgroup in both DAS-ELISA and IEM decoration experiments (Table 3) were most striking. Since GRAV is most closely related to $\mathrm{CpCSV}$ in $\mathrm{CP}$ sequence, the GRAV antiserum should give stronger IEM reactions with CpCSV-FB virions than antisera to BWYV subgroup viruses. However, the contrary was observed, which might be due to the poor quality of the GRAV antiserum. Another, and perhaps more likely explanation, is that CpCSV-FB shares more virion surface epitopes with BWYV subgroup viruses, such as BMYV and TuYV, than with GRAV.

The aforementioned cross-reactions were confirmed by TASELISA reactions of Mab $510 \mathrm{H}$ with CpCSV-FB and with other CpCSV isolates (unpublished data). The reaction pattern of Mab $510 \mathrm{H}$ was similar to that of the antisera to viruses of the BWYV subgroup, suggesting that the latter share at least one immunodominant epitope with CpCSV. In this respect, Mab 510H appears to resemble Mab PAV-IL1 raised against BYDV-PAV and used for the discrimination of BWYV-like viruses $(12,27,59,61)$. Our observation that Mab $510 \mathrm{H}$ cross-reacts with CpCSV may have important implications as this Mab has been commercially available as PVAS-647 from the American Type Culture Collection (ATCC) and often used for the serological identification of BWYV in legume crops in several countries, such as Ethiopia (62), Iran (45), Iraq (42), Pakistan (39), Sudan (43), Syria (35), and Tunisia (54). Ellis and Wieczorek (15) had already shown that Mab $510 \mathrm{H}$ reacts not only with BWYV subgroup viruses but also with CYDV-RPV (formerly referred to as BYDV-RPV and considered a BWYV strain). Our studies confirm that Mab PVAS647 is not specific for BWYV. Hence, virus isolates identified in previous reports as BWYV based on their reaction with PVAS647 could in fact be CpCSV or a closely related virus, but not necessarily a virus of the BWYV subgroup.

Apart from the aforementioned unconfirmed reports on the serological identification of BWYV in legume crops, there is molecular evidence for the occurrence of BWYV subgroup viruses in legumes in Morocco (19), India (53), and Europe (27). Because of the cross-reactivity of the CpCSV-FB antiserum with viruses of the BWYV subgroup (Table 3), a more specific serological tool for routine detection of $\mathrm{CpCSV}$ in field samples was required. Therefore, Mabs were raised against CpCSV-FB virions and shown to react only with CpCSV. In addition, each of the 10 Mabs reacted with all the CpCSV-infected samples from chickpea, faba bean, lentil, grasspea, and fenugreek, indicating that the epitopes recognized by the available Mabs are conserved among Ethiopian isolates of CpCSV. Since the mono- and polyclonal antibodies produced here permitted both sensitive and specific TAS-ELISA detection of CpCSV, they appear to be useful for CpCSV detection in legume crops in Ethiopia. Our observations that all Mabs failed to give a western blot reaction with CpCSVFB CP and only 2 of the 10 Mabs weakly decorated CpCSV-FB particles suggest that all Mabs recognize conformation-sensitive epitopes that appear to be predominantly internal. Moreover, we do not know whether they react with the major or minor (readthrough) CP. While the majority of Mabs to luteovirids have apparently not been tested in western blots with luteovirid CPs, there are numerous examples from other plant virus groups (20) supporting our observation that virus-specific Mabs do not necessarily produce reactions in western blots.

Our data underline the need for virus identification to depend on at least two independent characteristics of a virus (e.g., serology, nucleotide sequence). The availability of the antiserum and Mabs to $\mathrm{CpCSV}$ as well as sequence data described here will be of vital importance for CpCSV detection and identification, for determining its diversity/variability, and for assessment of its relative importance. All of this information will be crucial for resistance breeding and for developing strategies of CpCSV control.

\section{ACKNOWLEDGMENTS}

This work was supported partly by a scholarship from German Academic Exchange Service (DAAD) to A. Abraham. We thank C. Maass and A. Sieg-Müller for excellent technical assistance; all those colleagues listed in Table 1 for the gifts of antisera and antibodies (in particular, R. R. Martin, Corvallis, OR, for kindly providing ascitic fluid containing Mab $510 \mathrm{H}$ and F. Rabenstein, Aschersleben, Germany, for antisera to BMYV and TuYV, for the Mabs T-4D3, -1E1, and -2G5, and for BMYV and TuYV isolates); and S. Winter and D. Stenger for critical review of the manuscript.

\section{LITERATURE CITED}

1. Abraham, A., and Makkouk, K. M. 2002. The incidence and distribution of seed-transmitted viruses in pea and lentil seed lots in Ethiopia. Seed Sci. Technol. 30:567-574.

2. Abraham, A., Makkouk, K. M., Gorfu, D., Lencho, A. G., Ali, K., Tadesse, N., Yusuf, A., and Lencho, A. 2000. Survey of faba bean (Vicia faba L.) virus diseases in Ethiopia. Phytopathol. Mediterr. 39:277-282.

3. Adam, G., Lesemann, D.-E., and Vetten, H. J. 1991. Monoclonal antibodies against tomato spotted wilt virus: Characterization and application. Ann. Appl. Biol. 118:87-104. 
4. Ali, K., and Habtewold, T. 1994. Research on insect pests of cool-season food legumes. Pages 367-396 in: Cool-Season Food Legumes in Ethiopia. Proceedings of the First National Cool-Season Food Legumes Review Conference. A. Telaye, G. Bejiga, M. C. Saxena, and M. B. Solh, eds. Institute of Agricultural Research, Addis Ababa, Ethiopia/ICARDA, Aleppo, Syria.

5. Altschul, S. F., Madden, T. L., Schaffer, A. A., Zhang, Z. H., Zhang, Z., Miller, W. W., and Lippman, D. J. 1997. Gapped BLAST and PSIBLAST: A new generation of protein database search programs. Nucleic Acids Res. 25:3389-3402.

6. Ashby, J. W. 1984. Bean leaf roll virus. No. 286 in: Descriptions of Plant Viruses. Commonw. Mycol. Inst./Assoc. Appl. Biol., Kew, England.

7. Ashoub, A., Rohde, W., and Prüfer, D. 1998. In planta transcription of a second subgenomic RNA increases the complexity of the subgroup 2 luteovirus genome. Nucleic Acids Res. 26:420-426.

8. Bos, L., Hampton, R. O., and Makkouk, K. M. 1988. Viruses and virus diseases of pea, lentil, faba bean and chickpea. Pages 591-615 in: World Crops: Cool Season Food Legumes. R. J. Summerfield, ed. Kluwer Academic Publishers, Dordrecht/Boston/London.

9. Bosque-Perez, N. A., and Buddenhagen, I. W. 1990. Studies on epidemiology of virus disease of chickpea in California. Plant Dis. 74:372-378.

10. Clark, M. F., and Adams, A. N. 1977. Characteristics of the microplate method of enzyme-linked immunosorbent assay for the detection of plant viruses. J. Gen. Virol. 34:475-483.

11. D'Arcy, C. J., and Domier, L. L. 2005. Luteoviridae. Pages 343-352 in: Virus Taxonomy. VIIIth Report of the International Committee on Taxonomy of Viruses. C. M. Fauquet, M. A. Mayo, J. Maniloff, U. Desselberger, and L. A. Balls, eds. Academic Press, New York.

12. D'Arcy, C. J., Torrance, L., and Martin, R. R. 1989. Discrimination among luteoviruses and their strains by monoclonal antibodies and identification of common epitopes. Phytopathology 79:869-873.

13. Demler, S. A., De Zoeten, G. A., Adams, G., and Harris, K. F. 1995. Pea enation mosaic virus: Properties, and aphid transmission. Pages 303-344 in: The Plant Viruses 5: Polyhedral Virions and Bipartite Genomes. B. D. Harrison and A. F. Murant, eds. Plenum Press, New York and London.

14. Dieffenbach, C. W., and Dveksler, G. A. 1995. PCR Primer: A Laboratory Manual. Cold Spring Harbor Laboratory, Cold Spring Harbor, NY.

15. Ellis, P. J., and Wieczorek, A. 1992. Production of monoclonal antibodies to beet western yellows virus and potato leafroll virus and their use in luteovirus detection. Plant Dis. 76:75-78.

16. Food and Agriculture Organization of the United Nations (FAO). 2004. FAO Statistical Databases. http://apps.fao.org/faostat (last accessed in December 2004)

17. Fortass, M. F., and Bos, L. 1991. Survey of faba bean (Vicia faba L.) for viruses in Morocco. Neth. J. Plant Pathol. 97:369-380.

18. Fortass, M. F., van der Wilk, F., Goldbach, R. W., Bos, L., and van den Heuvel, J. F. J. M. 1996. Diversity of viruses infecting faba bean in Morocco and their detection by the polymerase chain reaction. Agronomie 16:61-68.

19. Fortass, M. F., van der Wilk, F., van den Heuvel, J. F. J. M., and Goldbach, R. W. 1997. Molecular evidence for the occurrence of beet western yellows virus on chickpea in Morocco. Eur. J. Plant Pathol. 103:481-484

20. Franz, A., Makkouk, K. M., Katul, L., and Vetten, H. J. 1996. Monoclonal antibodies for the detection and differentiation of faba bean necrotic yellows virus isolates. Ann. Appl. Biol. 128:255-268.

21. Gibbs, M. J., Armstrong, J. S., and Gibbs, A. J. 2000. Sister-scanning: A Monte Carlo procedure for assessing signals in recombinant sequences. Bioinformatics 16:573-582.

22. Gorbalenya, A. E., and Koonin, E. V. 1989. Viral proteins containing the purine NTP-binding sequence pattern. Nucleic Acids Res. 17:8413-8439.

23. Gray, S., and Gildow, F. E. 2003. Luteovirus-aphid interactions. Annu. Rev. Phytopathol. 41:539-566.

24. Guilley, H., Catherine, W.-S., Richards, K., Lecoq, H., and Jonard, G. 1994. Nucleotide sequence of cucurbit aphid-borne yellows virus. Virology 202:1012-1017.

25. Gutierrez, P. A., Morgan, D. J., and Havenstein, D. E. 1971. The ecology of Aphis craccivora Koch and subterranean clover stunt virus I. The phenology of aphid populations and the epidemiology of virus on pasture in SE Australia. J. Appl. Ecol. 8:699-721.

26. Hauser, S., Stevens, M., Beuve, M., and Lemaire, O. 2002. Biological properties and molecular characterization of beet chlorosis virus (BChV). Arch. Virol. 147:745-762.

27. Hauser, S., Stevens, M., Mougel, C., Smith, H. G., Fritsch, C., Herrbach, E., and Lemaire, O. 2000. Biological, serological, and molecular variability suggest three distinct polerovirus species infecting beet or rape. Phytopathology 90:460-466.

28. Horn, N. M., Makkouk, K. M., Kumari, S. G., van den Heuvel, J. F. J. M., and Reddy, D. V. R. 1995. Survey of chickpea (Cicer arietinum L.) for chickpea stunt disease and associated viruses in Syria, Turkey and Lebanon. Phytopathol. Mediterr. 34:192-198.
29. Hull, R., and Adams, A. N. 1968. Groundnut rosette and its assistor virus. Ann. Appl. Biol. 62:139-145.

30. Hulluka, M., and Tadesse, N. 1994. Chickpea and lentil disease research in Ethiopia. Pages 346-366 in: Cool-Season Food Legumes in Ethiopia. Proceedings of the First National Cool-Season Food Legumes Review Conference. A. Telaye, G. Bejiga, M. C. Saxena, and M. B. Solh, eds. Institute of Agricultural Research, Addis Ababa, Ethiopia/ICARDA, Aleppo, Syria.

31. Iwaki, M., Roechan, M., Hibino, H., Tochihara, H., and Tantera, D. M. 1980. A persistently aphidborne virus of soybean, Indonesian soybean dwarf virus. Plant Dis. 64:1027-1030.

32. Kamer, G., and Argos, P. 1984. Primary structural comparison of RNAdependent polymerases from plant, animal and bacterial viruses. Nucleic Acids Res. 12:7269-7282.

33. Katul, L. 1992. Serological and molecular characterization of bean leaf roll virus and faba bean necrotic yellows virus (in German). Ph.D. thesis. University of Göttingen, Germany.

34. Koonin, E. V., and Dolja, V. V. 1993. Evolution and taxonomy of positivestranded RNA viruses: Implication for comparative analysis of amino acid sequences. Crit. Rev. Biochem. Mol. Biol. 28:375-430.

35. Kumari, S. G., Makkouk, K. M., Altar, N., Ghulam, W., and Lesemann, D.-E. 2004. First report of Chickpea chlorotic dwarf virus infecting spring chickpea in Syria. Plant Dis. 88:424.

36. Laemmli, U. K., and Favre, M. 1973. Maturation of the head of the bacteriophage T4. J. Mol. Biol. 80:575-599.

37. Lecoq, H., Bourdin, D., Wipf-Scheibel, C., Bon, M., Lot, H., and Lemaire, O. 1992. A new yellowing disease of cucurbits caused by a luteovirus, cucurbit aphid-borne yellows virus. Plant Pathol. 41:749-761.

38. Mäkinen, K., Tamm, T., Naess, V., Truve, E., Puurand, U., Munthe, T., and Saarma, M. 1995. Characterization of cocksfoot mottle sobemovirus genomic RNA and sequence comparison with related viruses. J. Virol. 76:2817-2825.

39. Makkouk, K. M., Bashir, M., and Jones, R. 1998. First record of faba bean necrotic yellows virus and Beet western yellows luteovirus affecting lentil and chickpea in Pakistan. Plant Dis. 82:591.

40. Makkouk, K. M., Bos, L., Azzam, O. I., Kumari, S., and Rizkallah, A. 1988. Survey of viruses affecting faba bean in six Arab countries. Arab J. Plant Prot. 6:61-53.

41. Makkouk, K. M., Damsteegt, V., Johnstone, G. R., Katul, L., Lesemann, D.-E., and Kumari, S. G. 1997. Identification and some properties of soybean dwarf luteovirus affecting lentil in Syria. Phytopathol. Mediterr. 36:135-144.

42. Makkouk, K. M., El-Muadhidi, M. A., and Kumari, S. G. 2001. First record of Beet western yellows virus, Chickpea chlorotic dwarf virus and Faba bean necrotic yellows virus affecting faba bean (Vicia faba) crops in Iraq. Plant Pathol. 50:793.

43. Makkouk, K. M., Hamed, A. A., Hussein, M., and Kumari, S. G. 2003. First report of Faba bean necrotic yellows virus (FBNYV) infecting chickpea (Cicer arietinum) and faba bean (Vicia faba) crops in Sudan. Plant Pathol. 52:412.

44. Makkouk, K. M., Kumari, S. G., Hughes, J. d'A., Muniyappa, V., and Kulkarni, N. K. 2003. Other legumes. Pages 447-476 in: Virus and VirusLike Diseases of Major Crops in Developing Countries. G. Loebenstein and G. Thottappilly, eds. Kluwer Academic Publishers, Dordrecht/Boston/ London.

45. Makkouk, K. M., Kumari, S. G., Shahraeen, N., Fazlali, Y., Farzadfar, S., Ghotbi, T., and Mansouri, R. A. 2003. Identification and seasonal variation of viral diseases of chickpea and lentil in Iran. J. Plant Dis. Prot. 110:157-169.

46. Martin, R. R., Keese, P., Young, M. J., Waterhouse, P. M., and Gerlach, W. L. 1990. Evolution and molecular biology of luteoviruses. Annu. Rev. Phytopathol. 28:341-363.

47. Miller, J. S., and Mayo, M. A. 1991. The location of the 5' prime end of potato leafroll virus subgenomic coat protein mRNA. J. Gen. Virol. 72:2633-2638

48. Miller, W. A., Dinesh-Kumar, S. P., and Paul, C. P. 1995. Luteovirus gene expression. Crit. Rev. Plant Sci. 14:179-211.

49. Miller, W. A., Koev, G., and Mohan, B. R. 1997. Are there risks associated with transgenic resistance to luteoviruses? Plant Dis. 81:700-710.

50. Milne, R. G. 1984. Electron microscopy for the identification of plant viruses in in vitro preparations. Methods Virol. VII:87-120.

51. Milne, R. G., and Lesemann, D.-E. 1984. Immunosorbent electron microscopy in plant virus studies. Methods Virol. VIII:85-101.

52. Naidu, R. A., Kimmins, F. M., Deom, C. M., Subrahmanyam, P., Chiyembekeza, A. J., and van der Merwe, P. J. A. 1999. Groundnut rosette: A virus disease affecting groundnut production in sub-Saharan Africa. Plant Dis. 83:700-709.

53. Naidu, R. A., Mayo, M. A., Reddy, S. V., Jolly, C. A., and Torrance, L. 1997. Diversity among coat proteins of luteoviruses associated with chickpea stunt disease in India. Ann. Appl. Biol. 130:37-47. 
54. Najar, A., Kumari, S. G., and Makkouk, K. M. 2003. A survey of viruses affecting faba bean (Vicia faba) in Tunisia includes first record of Soybean dwarf virus. Plant Dis. 87:1151.

55. Page, G. D. 1996. Treeview: An application to display phylogenetic trees on personal computers. Comput. Appl. Biosci. 12:357-358.

56. Reddy, S. V., and Kumar, L. P. 2004. Transmission and properties of a new luteovirus associated with chickpea stunt disease in India. Curr. Sci. 86:1157-1160.

57. Reutenauer, A., Ziegler-Graff, V., Lot, H., Sheidecker, D., Guilley, H., Richards, K., and Jonard, D. 1993. Identification of beet western yellows virus genes implicated in viral replication and particle morphogenesis. Virology 195:692-699.

58. Sambrook, J., Fritsch, E. F., and Maniatis, T. 1989. Molecular Cloning: A Laboratory Manual. 2nd ed. Cold Spring Harbor Laboratory, Cold Spring Harbor, NY.

59. Schubert, J., Rabenstein, F., Graichen, K., and Richter, K. 1998. Comparison of $5^{\prime}$ end nucleotide sequences of luteoviruses from oilseed rape and sugar beet. Arch. Phytopathol. Pflanzenschutz. 31:519530 .

60. Scott, K. P., Farmer, M.-J., Robinson, D. J., Torrance, L., and Murant, A. F. 1996. Comparison of the coat protein of groundnut rosette assistor virus with those of other luteoviruses. Ann. Appl. Biol. 128:77-83.

61. Stevens, M., Smith, H. G., and Hallsworth, P. B. 1994. Identification of a second distinct strain of beet mild yellowing luteovirus using monoclonal antibodies and transmission studies. Ann. Appl. Biol. 125:515-520.

62. Tadesse, N., Ali, K., Gorfu, D., Yusuf, A., Abraham, A., Ayalew, M., Lencho, A., Makkouk, K. M., and Kumari, S. G. 1999. Survey of chickpea and lentil virus diseases in Ethiopia. Phytopathol. Mediterr. 38:149-158

63. Takanami, Y., and Kubo, S. 1979. Enzyme-assisted purification of two phloem-limited plant viruses: Tobacco necrotic dwarf and potato leafroll. Ann. Appl. Biol. 44:153-159.

64. Tamada, T., and Kojima, M. 1977. Soybean dwarf virus. No. 179 in: Descriptions of Plant Viruses. Commonw. Mycol. Inst./Assoc. Appl. Biol., Kew, England.

65. Telaye, A., Bejiga, G., and Berhe, A. 1994. Role of cool-season food legumes and their production constraints. Pages 3-18 in: Cool-Season Food Legumes in Ethiopia. Proceedings of the First National Cool-Season Food Legumes Review Conference. A. Telaye, G. Bejiga, M. C. Saxena, and M. B. Solh, eds. Institute of Agricultural Research, Addis Ababa, Ethiopia/ICARDA, Aleppo, Syria.

66. Thompson, J. D., Gibson, T. B., Plewniack, F., Jeanmougin, F., and Higgins, D. G. 1997. The ClustalX windows interface: Flexible strategies for multiple sequence alignment aided by quality analysis tool. Nucleic Acids Res. 25:4876-4882.

67. van der Wilk, F., Verbeek, M., Dullemans, A. M., and van Den Heuvel, J. F. J. M. 1997. The genome-linked protein of potato leaf roll virus is located downstream of the putative protease domain of the ORF1 product. Virology 234:300-303.

68. Veidt, I., Lot, H., Leiser, M., Scheidecker, D., Guilley, H., Richards, K., and Jonard, G. 1988. Nucleotide sequence of beet western yellows virus RNA. Nucleic Acids Res. 16:9917-9932.

69. Vetten, H. J., Lesemann, D.-E., and Maiss, E. 1992. Serotype A and serotype B strains of bean common mosaic virus are two distinct potyviruses. Arch. Virol. Suppl. 5:415-431. 